\title{
Peran Dompet Dhuafa Banten Dalam Pembangunan Sanitasi di Kampung SEHATI
}

\section{Deliya Gustiani ${ }^{1}$}

FISIP, Universitas Sultan Ageng Tirtayasa

deliyag22@gmail.com

\section{Risya Aprilia Dwiningtias ${ }^{2}$}

FISIP, Universitas Sultan Ageng Tirtayasa risyaaprilia220@yahoo.com

\section{E-ISSN (2721-0642)}

Recieved:

June 102020

Revised:

December 112020

Accepted:

December 142020

Doi Number

https://doi.org/10.37950/ijd.v2i3.59

\section{Abstract}

The empowerment proposed by Shardlow (1998) illustrates how a person, to a group or community can strive to control his own life and try to make his future in accordance with what he wants. One type of empowerment is environmental and health based empowerment. Community and health-based empowerment can foster awareness and awareness from the community itself about the importance of maintaining health through environmental cleanliness. One of the non-governmental organizations that empowered in the field of health and the environment was Dompet Dhuafa Banten, which established the Sanitation Healthy Village (SEHATI) located in Ciwaru Village, Cipocok Jaya District, Serang City. Empowerment carried out by the Dompet Dhuafa Banten is empowering sanitation by building sanitation in community homes. Therefore this research was conducted to see how the Dompet Dhuafa Banten empowered the community by implementing the theory of empowerment from Shardlow.

Keywords: community empowerment, sanitation, health.

\section{Abstrak}

Pemberdayaan yang dikemukakan oleh Shardlow (1998) menggambarkan bagaimana seseorang, sampai dengan kelompok atau komunitas dapat mengupayakan untuk mengkontrol kehidupannya sendiri serta berusaha agar masa depannya sesuai dengan apa yang ia inginkan. Salah satu macam pemberdayaan ialah pemberdayaan berbasis lingkungan dan kesehatan. Pemberdayaan masyarakat yang berbasis kesehatan dan lingkungan dapat menumbuhkan kesadaran, serta rasa kepedulian dari masyarakat itu sendiri tentang pentingnya menjaga 
kesehatan melalui kebersihan lingkungannya. Salah satu organisasi non pemerintah yang melakukan pemberdayaan di bidang kesehatan dan lingkungan adalah Dompet Dhuafa Banten yang mendirikan Kampung Sehat Sanitasi (SEHATI) yang terletak di Kampung Ciwaru, Kecamatan Cipocok Jaya, Kota Serang. Pemberdayaan yang dilakukan oleh Dompet Dhuafa Banten ialah pemberdayaan sanitasi dengan cara membangun sanitasi di rumah masyarakat. Maka dari itu penelitian ini dilakukan guna melihat bagaimana Dompet Dhuafa Banten melakukan pemberdayaan masyarakat tesebut dengan pengimplementasian dari teori pemberdayaan dari Shardlow.

Kata Kunci : pemberdayaan masyarakat, sanitasi, kesehatan

\section{Pendahuluan}

Kesehatan merupakan faktor yang sangat penting untuk dijaga. Apabila kita tidak menjaga kesehatan, aktivitas sehari-hari akan terganggu. Salah satu bentuk menjaga kesehatan bisa dimulai dengan cara menjaga selalu kebersihan lingkungan. Karena wilayah permukiman yang sehat juga ditandai dengan wilayah yang bersih sangatlah mempengaruhi kesehatan masyarakat yang tinggal di wilayah wilayah tersebut. Jika ingin menciptakan lingkungan yang bersih dan juga nyaman, sangat dibutuhkan peran dari setiap lapisan masyarakat. Lingkungan yang sehat sangatlah berpengaruh terhadap kualitas hidup dan kesehatan masyarakat.

Situasi dan kondisi lingkungan di sekitar tempat tinggal yang tidak terjaga atau bisa pula dikatakan tidak sehat menjadi salah satu faktor timbulnya penyakit, khususnya penyakit berbasis lingkungan. Salah satunya ialah, penyakit diare yang memiliki 3 faktor utama terjadinya penyakit diare. Faktor yang utama terjadinya penyakit diare adalah air bersih, pembuangan tinja, adan juga limbah. Selain situasi dan kondisi lingkungan tempat tinggal yang tidak sehat, kondisi sanitasi dasar yang buruk dan juga tidak sesuai dengan syarat kesehatan menjadi aspek penyebab berkembangnya penyakit.

Salah satu penyebab yang mempengaruhi kesehatan lingkungan ialah kesehatan dan kebersihan sanitasi. Sanitasi sangatlah penting untuk dijaga sebagai upaya dalam mencegah terjadinya gangguan kesehatan. Yang termasuk dalam upaya menjaga kebersihan sanitasi pada masyarakat dapat meliputi penyediaan air bersih, jamban dengan kondisi baik, pengelolaan limbah sampah yang baik, serta saluran pembuangan air limbah yang baik pula. Fokus riset kali ini adalah bagaimana menjaga kesehatan lingkungan khususnya jamban. Jamban atau tempat penampungan tinja manusia menjadi salah satu penyebab penyakit yang penularannya bisa berasal dari kuman ataupun virus yang ada di tinja masyarakat.

Permasalahan yang akan kami teliti adalah minimnya kesadaran yang dimiliki

oleh masyarakat Kota Serang terhadap kesehatan lingkungan, dengan masih banyaknya masyarakat di Kota Serang yang tidak memiliki jamban. Hal ini dapat terlihat dari kesadaran yang dimiliki oleh masyarakat RT01/RW08 Kampung Ciwaru, Kecamatan Cipocok Jaya, Kota Serang untuk membuang hajat pada tempat yang layak masih sangat kurang. Masyarakat cenderung lebih memilih buang air besar (BAB) di tempat yang tidak seharusnya. Seperti di sawah, sungai, selokan, maupun kali yang terletak di sekitar tempat tinggalnya.

Oleh karena itu, adanya permasalahan diatas salah satu NGO (Organisasi non pemerintah) yaitu Dompet Dhuafa Banten memiliki program: "Layanan Kesehatan 
Cuma-Cuma (LKC)". Dalam program Layanan Kesehatan Cuma-Cuma (LKC) ini, Dompet Dhuafa Banten memiliki program yang juga bekerjasama dengan Sanitasi Total Berbasis Masyarakat. Melalui program ini, Dompet Dhuafa Banten meluncurkan kegiatan yang dilakukan di RT01/RW08 Kampung Ciwaru, Kecamatan Cipocok Jaya, Kota Serang menjadi kampung pionir dalam usaha mempromosikan sanitasi sehat di Kota Serang. Kegiatan ini bertujuan untuk menyadarkan masyarakat bahwa buang hajat di sembarangan lokasi itu buruk, juga dapat menimbulkan terganggunya kesehatan bagi masyarakat.

Berdasarkan observasi yang sudah dilakukan, peneliti menemukan banyaknya masyarakat di RT01/RW08 Kampung Ciwaru, Kecamatan Cipocok Jaya, Kota Serang yang tidak memiliki jamban di tempat tinggalnya masing-masing. Ada beberapa hal yang akan diamati oleh peneliti adalah bagaimana peran Dompet Dhuafa dalam menyadarkan dan mengubah pola pikir masyarakat bahwa memiliki jamban merupakan hal yang penting dalam rangka menjaga kesehatan bagi masyarakat dan lingkungan sekitar.

Penelitian atau riset yang dilakukan ini memiliki tujuan, yaitu untuk memperoleh deskripsi dari pengimplementasian program Sanitasi Total Berbasis Masyarakat (STBM) yang dilaksanakan oleh Dompet Dhuafa dan Untuk mengetahui respon dari masyarakat RT01/RW08 Kampung Ciwaru, Kecamatan Cipocok Jaya, Kota Serang terhadap program Sanitasi Total Berbasis Mayarakat (STBM) yang diimplementasikan oleh Dompet Dhuafa Banten.

\section{Kerangka Teori}

\section{Teori Pemberdayaan Masyarakat}

Pemberdayaan menurut Shardlow (1998) pada kesimpulannya berbicara tentang bagaimana seorang individu, kumpulan maupun komunitas yang bergerak untuk mengatur kehidupannya dan berusaha akan membangun masa depan sesuai dengan apa yang sudah mereka inginkan.

Sesuai dengan apa yang telah dikemukakan oleh Shardlow (1998), Dompet Dhuafa merupakan organisasi non provit milik masyarakat yang bertujuan untuk mengangkat derajat sosial kaum dhuafa melalui dana ZISWAF (Zakat, Infaq, Shadaqah, Wakaf, dan juga dana lain yang halal mulai dari perorangan, kelompok, dan perusahaan ataupun lembaga). Awal mula berdirinya Dompet Dhuafa dari rasa kepedulian para jurnalis yang sering berinteraksi dengan masyarakat miskin. Maka dari itu, munculah ide untuk bersama-sama menggalang dana dengan kepada siapa saja yang merasa perduli terhadap kaum dhuafa.

Adapun hakikat pemberdayaan adalah salah satu proses dan juga usaha dalam mendapatkan maupun membagikan keahlian, keterampilan, kepandaian kepada individu atau masyarakat yang terbelakang supaya nantinya bisa mengidentifiksi dan menentukan setiap kepentingan, kemampuan, juga masalah yang nantinya akan dihadapi, sekalian memberikan solusi dalam penyelesaiannya dengan mengoptimalisasikan sumber daya dan juga kemampuan diri yang dimiliki secara mandiri.

Pada proses pemberdayaan, diperlukannya sebuah pencapaian dalam pemberdayaan melalui penerapan pendekatan pemberdayaan dalam penguatan, perlindungan, penyokongan dan juga pemeliharaan.

Tahapan dalam pemberdayaan yang dapat dilakukan, yakni sebagai berikut : 
1. Persiapan

2. Pengkajian

3. Perencanaan alternatif program

4. Pemformulasian rencana aksi

5. Pelaksanaan agenda atau kegiatan

6. Evaluasi

7. Terminasi

Macam-macam bentuk dalam pemberdayaan dapat dilakukan guna menciptakan kesejahteraan bagi masyarakat, seperti:

a. Pemberdayaan ekonomi

b. Pemberdayaan kesehatan

c. Pemberdayaan lingkungan

d. Pemberdayaan sosial dan budaya

Pada riset kali ini, peneliti mencoba memakai teori pemberdayaan di bidang kesehatan dan lingkungan. Agar nantinya lingkungan menjadi bersih, sehat dan nyaman, maka sangat dibutuhkan peran dari setiap lapisan masyarakat. Lingkungan yang sehat pun sangat berpengaruh terhadap kualitas hidup dan kesehatan masyarakat.

Pemberdayaan masyarakat di bidang kesehatan dilakukan yang bertujuan untuk membangun pemahaman, rasa kepedulian, dan kemauan masyarakat meningkatkan dan senantiasa menjaga kesehatan. Begitu juga dengan apa yang telah dijalankan oleh Dompet Dhuafa Banten, mereka berupaya untuk menyadarkan dan mengubah pola pikir masyarakat bahwa memiliki jamban merupakan hal yang penting dalam rangka menjaga kesehatan bagi masyarakat dan lingkungan sekitar.

Jika Dompet Dhuafa Banten mampu mengubah pola pikir masyarakat bahwa menjaga kesehatan itu penting, maka yang akan terwujud selanjutnya adalah kesehatan lingkungan yang terjaga, karena masyarakat sudah sadar bahwa memiliki jamban itu penting. Akibatnya, minimnya masyarakat yang buang hajat tidak pada tempatnya.

Tujuan dalam pemberdayaan itu sendiri untuk membangun kemampuan agar nantinya dapat meningkatkan diri menjadi lebih unggul lagi secara berkelanjutan. Maka dari itu, setiap pemberdayaan akan diarahkan dengan tujuan untuk memajukan kehidupan setiap manusia sehingga dapat menjadikan masyarakat yang maju.

\section{Sanitasi}

Menurut WHO (World Health Organization), yaitu sanitasi adalah pengelolaan dari seluruh aspek lingkungan fisik masyarakat yang bisa memunculkan dampak yang kurang baik terhadap aktivitas manusia, baik itu fisik maupun mental. Sanitasi menjadi salah satu aspek krusial dalam mempengaruhi peningkatan status kesehatan manusia. Pemenuhan sanitasi dapat diterapkan dalam rumah tangga maupun individu. Namun, sampaisaat ini pemenuhan sanitasi masih belum bisa diterapkan oleh seluruh masyarakat di Indonesia, khususnya pada masyarakat yang berada di RT01/RW08 Kampung Ciwaru, Kecamatan Cipocok Jaya, Kota Serang. Masih banyaknya masyarakat yang tidak memiliki pemikiran akan pentingnya sanitasi yang bersih dan sehat dan tidak memiliki fasilitas dari sanitasi dasar yang baik atau sinkron oleh standard (tolak ukur) yang sudah ditetapkan oleh pemerintah, sehingga saat ini angka kesakitan dari masyarakat yang disebabkan karena sanitasi yang buruk masih sangat tinggi. 
Sanitasi lingkungan merupakan status kesehatan dari suatu lingkungan yang mencakup perumahan, penampungan kotoran atau tinja, penyediaan air bersih, sarana pembuangan sampah, dan saluran pembuangan limbah ini juga biasa disebut sebagai sanitasi dasar. Sanitasi dasar sangat penting untuk dilakukan dalam rangka menjaga kualitas sanitasi lingkungan yang bersih dan sehat. Dari sanitasi lingkungan yang baik dan sehat, maka masyarakat tidak akan mudah terkena penyakit. Kondisi lingskungan yang tidak bersih dan sehat menjadi faktor utama masyarakat terjangkit penyakit. Khususnya penyakit berbasis lingkungan, seperti diare. Diare adalah salah satu penyakit yang dapat disebabkan oleh lingkungan kotor yang banyak memicu adanya kuman, virus, jamur, dan lain sebagainya. Penyakit diare mempunyai 3 faktor dominan, yaitu air bersih, pembuangan tinja dan limbah.

\section{Metode Penelitian}

Penelitian ini menggunakan metode kualitatif deskriptif. Metode kualitatif sendiri merupakan pemaparan fakta-fakta untuk menjawab rumusan masalah dari penelitian. Penelitian deskriptif menitik beratkan terhadap kondisi alami atau wajar yang mengungkapkan, menguraikan suatu situasi atau peristiwa. (Rakhmat,199:45)

Penelitian ini menggunakan metode penelitian kualitatif dengan pendekatan deskriptif yang bertempat di RT01/RW08 Kampung Ciwaru, Kecamatan Cipocok Jaya, Kota Serang. Penelitian deskriptif-kualitatif bertujuan untuk menggambarkan, meringkaskan kondisi dan situasi yang terjadi di Kampung SEHATI (Sehat Sanitasi). Dengan demikian format kualitatif deskiptif ini sangat cocok untuk digunakan dalam penelitian kami.

\section{Hasil dan Diskusi}

Rendahnya kesadaran yang dimiliki oleh masyarakat akan pentingnya menjaga kebersihan lingkungan masih menjadi masalah yang belum terselesaikan. Minimnya pendapatan juga menjadi salah satu faktor yang mengakibatkan masih banyaknya masyarakat yang acuh terhadap kebersihan lingkungan, khususnya di tempat tinggalnya. Tak terkecuali di Kampung Ciwaru RT01/RW08, Kecamatan Cipocok Jaya, Kota Serang masih banyak masyarakat yang bersikap tidak peduli dengan kebersihan tempat tinggalnya.

Dengan ditemukannya 40 rumah tempat tinggal warga setempat yang tidak memiliki jamban di Kampung Ciwaru RT01/RW08, Kecamatan Cipocok Jaya, Kota Serang. Karena keterbatasan biaya dan kesadaran, masyarakat cenderung memilih buang hajat di bukan tempatnya, seperti selokan, kali, bahkan di sawah yang letaknya berada di sekitar tempat tinggalnya. Dengan adanya permasalahan di atas, Dompet Dhuafa Banten berupaya untuk melakukan pemberdayaan masyarakat dengan cara membangun sanitasi di setiap rumah yang belum mempunyai jamban di Kampung Ciwaru RT01/RW08, Kecamatan Cipocok Jaya, Kota Serang.

Perlu diketahui bersama, Dompet Dhuafa adalah salah satu organisasi non provit milik masyarakat yang bertujuan untuk meningkatkan derajat sosial kaum dhuafa melalui dana ZISWAF (Zakat, Infaq, Shadaqah, Wakaf, dan juga dana lain yang halal mulai dari perorangan, kelompok, maupun perusahaan ataupun lembaga). Awal mula berdirinya Dompet Dhuafa berawal dari rasa kepedulian para jurnalis yang sering berinteraksi dengan masyarakat miskin dan juga seringkali dengan masyarakat yang 
mempunyai rezeki berlebih. Maka dari itu, munculah ide untuk bersama-sama menggalang dana dengan siapapun yang peduli terhadap kaum dhuafa.

Dompet Dhuafa memiliki lima bidang program kerja, yakni sebagai berikut :

1. Bidang Kesehatan

2. Bidang Pendidikan

3. Bidang Ekonomi

4. Bidang Sosial dan Dakwah

5. Bidang Budaya

Dalam penelitian ini, yang termasuk dalam program kerja Dompet Dhuafa adalah bidang kesehatan, melalui Program Layanan Kesehatan Cuma-Cuma (LKC). Layanan Kesehatan Cuma-Cuma (LKC) merupakan program kerja dari Dompet Dhuafa di bidang kesehatan yang melayani kaum dhuafa melalui dana sosial masyarakat dan dana sosial perusahaan (ZISWAF).

Sesuai dengan teori yang digunakan dalam penelitian ini, yaitu teori pemberdayaan masyarakat yang diungkapkan oleh Shardlow, beliau berpendapat bahwa ada proses atau tahapan yang dilalui sebelum tercapainya pemberdayaan masyarakat. Begitu juga dengan yang dilakukan oleh Dompet Dhuafa Banten dalam memberdayakan masyarakat untuk membangun sanitasi di Kampung Ciwaru ini pun melalui beberapa tahapan sesuai dengan yang dikemukakan oleh Shardlow, yaitu:

\section{Persiapan.}

Tentu saja sebelum turun langsung ke lapangan, Dompet Dhuafa Banten mempersiapkan segala macam yang harus dipenuhi dalam menjalankan program ini. Yang pertama kali adalah dengan mencari tahu daerah mana yang cocok untuk menjadi kampung pelopor sehat sanitasi, atau biasa disebut Kampung Sehati.

\section{Pengkajian}

Setelah ditemukan kampung yang cocok untuk dijadikan kampung pelopor sehat sanitasi, Dompet Dhuafa Banten melakukan pengkajian kembali terkait kampung ini. Pada awalnya DompetDhuafa Banten datang menemui RT08 dan ingin menjadikan sebagai kampung pelopor sehat sanitasi di RT02/RW08 Kampung Ciwaru, Kecamatan Cipocok Jaya, Kota Serang. Akan tetapi, melihat situasi dan kondisi di RT01/RW08 yang lebih memprihatinkan, akhirnya Dompet Dhuafa Banten memutuskan untuk membangun kampung pelopor sehat sanitasi di RT01/RW08 Kampung Ciwaru ini.

\section{Pemformulasian Rencana Aksi}

Dompet Dhuafa Banten bekerja sama dengan Tim Sanitasi Berbasis Masyarakat (STBM) dan pemerintah daerah setempat. Sebelumnya Dompet Dhuafa Banten dengan tim Sanitasi Total Berbasis Masyarakat (STBM) memberikan penyuluhan ataupun sosialisasi tentang kesehatan lingkungan kepada masyarakat di RT01/RW08 Kampung Ciwaru, Kecamatan Cipocok Jaya, Kota Serang. Pada tahapan ini, masyarakat menganggap sosialisasi atau penyuluhan ini hanyalah angin lalu saja. Tidak ada yang peduli karena keterbatasan biaya yang menjadi faktor utama penyebab masyarakat di RT01 ini masih hidup tidak sehat dengan tidak adanya jamban di setiap rumah.

Maka dari itu, melihat respon masyarakat yang kurang baik pada sosialisasi ini, Bapak Slawi selaku Ketua RT01 ini pun membantu Dompet Dhuafa Banten dan tim Sanitasi Total Berbasis Masyarakat untuk melakukan pendekatan dan memberikan pengertian terhadap masyarakat dengan cara mendatangi satu-persatu rumah 
masyarakat yang belum memiliki jamban untuk kemudian diberi nasehat yang dapat membangun kesadaran si pemilik rumah. Tidak hanya sekali, Bapak Slawi mendatangi rumah masyarakat satu-persatu sebanyak tiga kali, karena beliau menganggap bahwa, jika hanya sekali aksi yang dilakukan oleh Bapak ini, maka nasehat dan pengertian yang diberikan itu juga tidak akan melekat di diri si pemilik rumah.

\section{Pelaksanaan program atau kegiatan}

Setelah masyarakat sadar akan pentingnya sanitasi yang bersih di tempat tinggal, akhirnya dilaksanakanlah program pemberdayaan masyarakat oleh Dompet Dhuafa Banten dengan membangun sanitasi di tempat tinggal masyarakat yang belum mempunyai jamban. Pelaksanaan program ini dimulai pada tahun 2019, dengan waktu pembangunan sekitar 1,5 bulan. Masing-masing rumah yang ingin dibangun sanitasi, mendapatkan bantuan berupa tiga sak semen dan satu truk pasir dari Dompet Dhuafa Banten. Akan tetapi, bagi masyarakat yang benar-benar tidak mampu untuk membangun jamban dirumahnya, maka akan mendapatkan bantuan sepenuhnya dari Dompet Dhuafa Banten. Sampai saat ini program telah selesai, namun masih ada 2 rumah yang belum dibangun jamban. Pemilik rumah masih terus diberi pengertian oleh Bapak Slawi bahwa betapa pentingnya sanitasi di rumah.

\section{Evaluasi}

Setelah program ini selesai, dapat dilihat perubahan yang cukup signifikan di RT01/RW08 Kampung Ciwaru. Masyarakat menjadi lebih sehat dengan memiliki jamban disetiap rumahnya dan tidak lagi BAB sembarangan, selain itu lingkungan disekitar Kampung menjadi lebih bersih. Menurut peneliti, dapat dikatakan program yang dilakukan oleh Dompet Dhuafa Banten ini sudah sangat berhasil dalam rangka pemberdayaan masyarakat dalam bidang sanitasi. Tentu saja, program ini dapat berhasil dilakukan karena adanya kolaborasi yang terjalin serasi oleh semua pihak yang terlibat. Mulai dari Dompet Dhuafa Banten, Tim Sanitasi Berbasis Masyarakat, Ketua RT01 dan juga Masyarakat di Kampung Ciwaru.

Dengan adanya program Kampung Sehat Sanitasi (SEHATI) dari Dompet Dhuafa Banten di RT01/RW08 Kampung Ciawaru, Kecamatan Cipocok Jaya, Kota Serang menjadi salah satu contoh dari pemberdayaan masyarakat dalam bidang lingkungan dan kesehatan melalui pendekatan kepada masyarakat setempat akan pentingnya sanitasi yang sehat dan bersih guna menjaga kesehatan.

Sebelumnya masyarakat di RT01/RW08 Kampung Ciwaru tidak memiliki jamban dan acuh akan hal tersebut menjadi sadar dan ingin merubah kebiasaan buruknya tersebut. Karena salah satu dari sanitasi dasar adalah jamban. Maka dari itu setiap keluarga atau rumah haruslah memiliki jamban karena menjadi indikator kesehatan yang harus dipenuhi oleh setiap rumah dan keluarga. Jamban yang sehat menjadi fasilitas dalam memutus rantai penyebaran penyakit kepada manusia. Kebiasaan masyarakat RT01/RW08 Kampung Ciwaru yang sebelumnya lebih memilih Buang Air Besar (BAB) disembarang tempat menjadi hal yang beresiko dalam penyebaran penyakit, dengan adanya program Kampung Sehati yang dilakukan oleh Dompet Dhuafa Bantenini diharapkan dapat merubah kebiasaan dan menjadikan masyarakat di RT01/RW08 Kampung Ciwaru menjadi lebih sehat dan terus menjaga lingkungannya supaya nantinya dapat terhindar dari berbagai macam penyakit.

Diharapkan dengan adanya Kampung Sehati di RT01/RW08 ini diharapkan dapat terus menjaga kondisi lingkungannya agar derajatkesehatan bagi masyarakat 
menjadi optimal, serta dapat menjadi contoh bagi masyarakat yang berada disekitarnya menjadi sadar dan tergerak untuk merubah perilaku yang sebelumnya tidak memiliki jamban dan acuh akan pentingnya sanitasi yang bersih menjadi lebih sehat dan menjaga lingkungannya. Karena dengan kondisi sanitasi yang baik dan bersih sangatlah berpengaruh dan sangat berdampak pada kesehatan masyarakat.

\section{Kesimpulan}

Sanitasi merupakan hal yang penting bagi kelangsungan hidup setiap manusia terutama sanitasi lingkungan. Sanitasi lingkungan adalah salah satu upaya dalam mewujudkan lingkungan yang bersih dan sehat. Jika sanitasi lingkungan tidak ada maka akan menimbulkan banyak dampak negatif, seperti banyaknya penyakit yang timbul dan tentu saja merusak kelangsungan hidup manusia. Biasanya, di wilayah pedesaan masih banyak masyarakat yang tidak memiliki sanitasi di rumahnya masingmasing. Mereka masih cenderung abai dalam menjaga kesehatan dengan alasan tidak memiliki cukup biaya untuk membangun sanitasi di tempat tinggalnya. Ternyata permasalahan tersebut tidak saja terjadi di daerah pedesaan saja, fakta mengatakan bahwa di kawasan perkotaan pun masih banyak masyarakat yang tidak mempunyai sanitasi di rumahnya. Seperti di RT01/RW08 Kampung Ciwaru, Kecamatan Cipocok Jaya, Kota Serang salah satunya. Masyarakat disini banyak yang belum sadar akan pentingnya pola sanitasi lingkungan. Sehingga masyarakat masih saja banyak yang buang air besar sembarangan dikarenakan tidak adanya sanitasi (jamban) di rumahnya.

Melihat kondisi dan situasi tersebut organisasi non pemerintah, yaitu Dompet Dhuafa Banten mempunyai program pemberdayaan masyarakat dengan cara membangun sanitasi di setiap rumah yang tidak memiliki jamban di RT01/RW08. Tentunya sebelum dilaksanakannya program ini, memiliki beberapa tahapan yang harus dilakukam oleh Dompet Dhuafa Banten. Dimulai dari persiapan, pengkajian, pemformulasian rencana aksi, pelaksanaan kegiatan atau program, sampai ke evaluasi.

Melalui program Dompet Dhuafa Banten, yaitu Kampung Sehati (Kampung Sehat Sanitasi) menjadi pembuka jalan bagi masyarakat Kampung Ciwaru agar lebih memperhatikan kesehatan dan kebersihan sanitasi serta meninggalkan segala kebiasaan yang sebelumnya tidak baik bagi kesehatan dan lingkungan sekitar. Keberhasilan dalam program ini tentunya dengan kerjasama yang sangat baik antara Dompet Dhuafa Banten, Pemerintah setempat, serta tim Sanitasi Berbasis Masyarakat (STBM) yang dapat meyakinkan masyarakat setempat untuk meninggalkan kebiasaan sebelumnya. Dengan adanya program ini diharapkan masyarakat setempat menjadi lebih sehat, senantiasa menjaga lingkungkan serta kesehatan serta ikut serta untuk mengajak masyarakat di sekitar lingkungannya untuk menjaga serta memperhatikan kesehatan sanitasi yang dimilikinya.

\section{Tentang Penulis}

Deliya Gustiani Mahasiswi Semester 6 Jurusan Ilmu Pemerintahan, Fakultas Ilmu Sosial dan Ilmu Politik, Universitas Sultan Ageng Tirtayasa.

Risya Aprilia Dwiningtias Mahasiswi Semester 6 Jurusan Ilmu Pemerintahan, Fakultas Ilmu Sosial dan Ilmu Politik, Universitas Sultan Ageng Tirtayasa. 


\section{Ucapan Terimakasih}

Terimakasih kepada Dompet Dhuafa Banten yang telah memberikan informasi mengenai program Sehati yang dilaksanakan di RT01/RW08 Kampung Ciwaru, Kecamatan Cipocok Jaya, Kota Serang. Terimakasih juga kami ucapkan kepada Ketua RT 01 beserta masyarakat RT01/RW08 Kampung Ciwaru, Kecamatan Cipocok Jaya, Kota Serang yang senantiasa menjadi informan dalam penelitian ini. Tidak lupa kami ucapakan terimakasih sebanyak-banyaknya kepada dosen mata kuliah Politik Lingkungan karena memberi kami kesempatan untuk melakukan penelitian kali ini, beserta dosen Prodi Ilmu Pemerintahan lainnya yang selalu memberikan kami ilmu beserta kesempatan penelitian lainnya.

\section{Referensi}

Celesta, Almas Ghassani, dan Nurul Fitriyah. 2019. Gambaran Sanitasi Dasar di Desa Payaman Kabupaten Bojonegoro Tahun 2016. Jurnal Kesehatan Lingkungan, Vol.11(2).

http://www.dompetdhuafa.org/ (diakses pada tanggal 20 Februari 2020, pukul: 17.10).

Musfiroh, Lailatul, dan Slamet Sumarto. 2014. Pemberdayaan Masyarakat dalam Pelestarian Lingkungan Hidup Desa Jerukwangi Kecamatan Bangsri Kabupaten Jepara. UCEJ, Vol.3(1).

Noor Munawar, 2011. Pemberdayaan Masyarakat. Jurnal Ilmiah CIVIS, Volume 1, No.2.

Pramudyani, Avanti Vera Risti, Arif Setiawan, Arif Fajariyansyah, Galih Latiko Aji. 2019. Upaya Pemberdayaan Masyarakat Bidang Kesehatan Menuju Desa Siaga oleh KKN UAD di Watu Gajah dan Mertelu, Gendangsari, Gunung Kidul. Jurnal Pemberdayaan: Publikasi Hasil Pengabdian Kepada Masyarakat, Vol.3(1).

Sidhi, Alifia Nugrahaini, Mursid Raharjo dan Nikie Astorina Yunita Dewanti. 2016. Hubungan Kualitas Sanitasi Lingkungan dan Bakterisologis Air Bersih Terhadap Kejadian Diare Pada Balita di Wilayah Kerja Puskesmas Adiwerna Kabupaten Tegal. Jurnal Kesehatan Masyarakat, Vol.4(3).

Sulaeman, Endang Sutisna, Ravik Karsidi, Bhisma Murti, Drajat Tri Kartono, Waryana, Rifai Hartanto. 2012. Model Pemberdayaan Masyarakat Bidang Kesehatan, Studi Program Desa Siaga. Kesmas, Jurnal Kesehatan Masyarakat Nasional, Vol.7(4).

Supriyadi, dan Emilia Chandra. 2018. Penerapan Hygiene dan Sanitasi di Pondok Pesantren As`ad Seberang Kota Jambi Tahun 2016. Jurnal Ilmiah Batanghari Jambi, Vol.18(1).

Suwarni, Linda, Selviana, Eko Sarwono, Ufi Ruhama. 2018. Pemberdayaan Masyarakat Melalui PENKES (Pendidikan dan Kesehatan) untuk Meningkatkan Derajat Kesehatan Masyarakat. Jurnal Abdimas Mahakam, Vol.2(1).

Utami, Resty Aprilia. 2018. Dampak Sanitasi Lingkungan Terhadap Kesehatan Masyarakat di Wilayah Pesisir Kecamatan Kota Agung. Jurnal FKIP Unila.

Yefni, Muhammad Haris. 2019. Pemberdayaan Lingkungan Melalui Program Penyediaan Air Minum dan Sanitasi Berbasis Masyarakat (PAMSIMAS) Desa Padang Mutung Kampar. Jurnal Masyarakat Madani, Vol.4(1). 